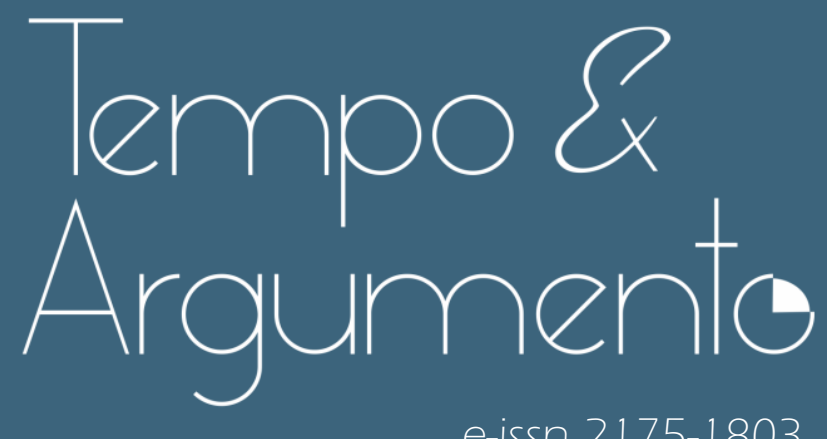

e-issn 2175-1803

I/Lustração Brasileira (Bordeaux/Paris, 1901-1902): em busca do projeto e de seus idealizadores

- Tania Regina de Luca

Doutora em História Social pela Universidade de São Paulo (USP).

Professora Livre-Docente da Universidade Estadual Paulista Júlio de

Mesquita Filho (UNESP).

Assis, SP - BRASIL

lattes.cnpq.br/4332049365505182

tania.luca@unesp.br

(D) orcid.org/ 0000-0002-8942-5237

Para citar este artigo:

LUCA, Tania Regina de. I/ustração Brasileira (Bordeaux/Paris, 190 1-1902): em busca do projeto e de seus idealizadores. Tempo e Argumento, Florianópolis, v. 13, n. 32, e0207, jan./abr. 2021.

do) http://dx.doi.org/10.5965/2175180313322021 e0207

Recebido: 23/09/2020

Aprovado: 04/03/2021 


\title{
Ilustração Brasileira (Bordeaux/Paris, 1901-1902): em busca do projeto e de seus idealizadores
}

\begin{abstract}
Resumo
O artigo tem por objetivo analisar os doze exemplares da revista /lustração Brasileira, mensário impresso na França e que circulou entre 1901 e 1902. O periódico é citado na historiografia como um dos pioneiros no uso da fotografia e colocado ao lado das revistas de variedades que se multiplicaram a partir do início do século XX, momento em que a impressão direta da fotografia nos impressos periódicos tornou-se possível. A despeito de ser muito mencionada, não se conta com estudos sistemáticos sobre essa revista e nem com informações a respeito dos objetivos ou dos responsáveis pelo empreendimento. Dados esparsos provenientes de jornais da época, associados à análise dos conteúdos e dos colaboradores, fornecem algumas pistas que ajudam a esclarecer pelo menos parte do problema e a elucidar a natureza da publicação, lançada num momento em que inovações técnicas abriam novas possibilidades para as revistas ilustradas.
\end{abstract}

Palavras-chave: Ilustração brasileira. Imprensa ilustrada. Usos da fotografia.

\section{Ilustração Brasileira (Bordeaux/Paris, 1901-1902): in search of project and its creator}

\begin{abstract}
The article aims to analyze the magazine Ilustração Brasileira. Between 1901 and 1902 twelve issues were published all of them printed in France. In the Brazilian historiography, one can find many mentions regarding the magazine, but they are always brief and superficial. Ilustração belongs to the set of periodicals founded in the beginning of twenty century and they were already able to print photographs, thanks to the new technological process. Despite being widely cited, there is no systematic studies about this periodical and one do not have data about its objectives and who was responsible for the project. Fragmentary and rare information collected from newspapers, associated with the analysis of content and collaborators of the monthly, provide some clues that help to clarify, at least part, of the problem and characterize the nature of the publication, founded at a time when technical innovations opened up new possibilities for illustrated magazines.
\end{abstract}

Keywords: Ilustração Brasileira. Illustrated press. Uses of photography. 
Desde meados da década de 1850, podem-se encontrar diversos periódicos que, em seus títulos, evocavam os termos ilustração/ilustrado(a), a começar pela Ilustração Brasileira (RJ, 1854-1855), O Brasil Ilustrado: publicação literária (RJ, 1855-1856), O Universo Ilustrado: pitoresco e monumental (RJ, 18581859), Ilustração Brasileira: jornal enciclopédico (RJ, 1861); Ilustração Americana. Jornal do Novo Mundo (RJ, 1870), Ilustração do Brasil (RJ, 1876-1880); Ilustração Popular (RJ, 1876-1877), Ilustração Brasileira: jornal de artes, ciências e letras (RJ, 1876-1878), O Globo Ilustrado (RJ, 1881-1882), A llustração (Paris, 1884-1892), 0 Brasil Ilustrado (RJ, 1887-1888). Não se trata de listagem exaustiva, mas de alguns títulos que foram produzidos ou circularam no Rio de Janeiro e que integravam o rol das publicações ditas sérias, ou seja, cuja proposta editorial era bem diversa da levada a efeito pelas humorísticas, a exemplo das célebres Semana Ilustrada (RJ, 1860-1876) e Revista llustrada (RJ, 1876-1898), que reivindicavam a mesma adjetivação.

A ambição era a de aproximar-se das congêneres europeias, cujas matriz inaugural foi The Illustrated London News (Londres, 1842), logo seguido pela L'lllustration (Paris, 1843) e Illustrierte Zeitung (Leipzig, 1843), publicações caras, sofisticadas graficamente e em grande formato, que reservavam metade de suas 16 páginas para estampas que, tanto ou mais do que informar, esperavam seduzir, num momento em que o conteúdo visual ainda apresentava o sabor das novidades. Não se tratava de produzir ou publicizar notícias, tal como as entendemos hodiernamente, mas de difundir atualidades numa conjuntura marcada pela aceleração da circulação da informação graças ao vapor, que movimentava locomotivas e navios por entre continentes e oceanos, e ao telégrafo, que colocou no horizonte do possível a noção de instantaneidade, hoje tão em voga.

Do rol de títulos acima mencionado, foi $A$ llustração que cumpriu plenamente essa missão, mas para isso teve que ser impressa em Paris e remetida, a cada quinze dias, do porto de Bordeaux para Lisboa e daí seguir viagem até o Rio de Janeiro. O negócio mostrou-se rentável em função tanto dos custos da impressão, realizada nas mesmas oficinas do Le Monde Illustré (Paris, 1857), mensário concorrente da Illustration, o que lhe garantia excelência gráfica 
inatingível nas condições vigentes em Portugal e no Brasil, quanto pelo fato de a revista valer-se, por quantia bastante modesta, das matrizes imagéticas produzidas para o Le Monde. Esses fatores explicam a qualidade e o preço competitivo, em vista das congêneres produzidas nos dois lados do Atlântico, fosse no Brasil ou em Portugal. Contudo, frente à pequena relevância do mundo luso-brasileiro para o leitor francês, a presença desses países nas páginas da bela revista era pequena, ou seja, havia que sacrificar o local em prol da sofisticação material (LUCA, 2018).

Em contraposição, os periódicos do mesmo gênero produzidos no Brasil apresentavam resultados bem mais modestos em termos de quantidade e qualidade das estampas, contassem apenas com recursos locais, como foi o caso, por exemplo, do segundo Brasil Ilustrado, datado dos anos 1880, ou também recorressem à importação de matrizes da Europa e dos Estados Unidos, prática bastante disseminada e que alerta para a existência de um ativo e vigoroso mercado internacional, responsável por abastecer periódicos de diferentes países e que se constituía numa forma de obter retorno do investimento requerido para a produção das matrizes, o que envolvia diversos profissionais/artistas especializados (desenhistas, gravadores, fotógrafos), além da preparação, a partir de diferentes técnicas, de clichês para a impressão tipográfica e as eventuais cópias para atender à demanda internacional. ${ }^{1}$

A bibliografia especializada tem destacado as dificuldades enfrentadas no Brasil - e também os esforços e os bons resultados obtidos - na produção de estampas ao longo do Oitocentos (ANDRADE, 2004; FERREIRA, 1994), situação que ganhou novos contornos a partir do início da centúria seguinte, quando a reprodução direta da fotografia em periódicos difundiu-se em larga escala, o que obviamente não implica em inexistência de exemplos anteriores. ${ }^{2}$

Desde o surgimento da fotografia, entrou na ordem do dia a corrida pela busca de soluções técnicas que compatibilizassem a impressão tipográfica com

\footnotetext{
Sobre a produção de imagens nos decênios iniciais do The Illustrated London News, também vigente nas demais ilustrações europeias, ver a obra do gravador e diretor artístico da revista inglesa por décadas (JACKSON, 1885).

2 O jornal pioneiro foi The Daily Graphic (Nova York, 1873), que publicou, em 04/03/1880, a foto $A$ Scene in Shantytown. No que respeita às diversas ilustrações europeias, há exemplos, ainda que bissextos, mencionados por Andrade (2004, p. 205-213).
} 
a reprodução direta do registro mecânico. As fotos tornaram-se, a partir de meados do século XIX, presença incontornável nos ateliês de desenhistas e gravadores, tanto que se multiplicaram nas legendas dos periódicos ilustrados a informação "a partir de/cópia fiel de fotografia”, fato que, por um lado, denotava o intuito de assegurar fidelidade em relação ao original e, por outro, admitia não se tratar da percepção direta, mas do resultado de trabalhos de mediação e interpretação. Estavam em jogo não apenas os custos envolvidos no processo de fabricação das matrizes, mas também a supressão da distância entre o que era capturado pela objetiva e o que se apresentava ao leitor.

Cabe observar que datam de fins dos anos 1870 e do início do decênio seguinte as contribuições de Charles-Guillaume Petit, Frederic Ives e, sobretudo, Georg Meisenbach, que permitiram finalmente solucionar a questão. O processo, denominado autotipia, similigravura, meio-tom ou meia-tinta baseava-se na decomposição das tonalidades contínuas da fotografia graças à utilização de uma retícula que as convertia em pontos cujas dimensões variavam em função da intensidade do original. ${ }^{3}$ Tal circunstância, porém, esteve longe de acarretar a imediata substituição dos ateliês de desenhistas, gravadores e responsáveis pelas formas anteriores de transposição de imagens, como evidenciam estudos realizados a partir dos arquivos da lllustration, que apontam as resistências e hibridismos que marcaram a produção das matrizes no período compreendido entre 1880 e 1900, uma vez que à percepção de que o valor artístico continuava prerrogativa do trabalho artesanal, somavam-se os interesses corporativos de artistas, as práticas consolidadas nas tradicionais revistas ilustradas europeias e o hábito dos leitores (GERVAIS, 2003, 2009), ou seja, a existência de um procedimento técnico não implica na sua utilização imediata, o que alerta para o complexo processo de sua incorporação, que não se subordina às temporalidades retilíneas.

As hesitações, porém, acabaram por ceder frente aos subsequentes aperfeiçoamentos tanto das câmeras, com a incorporação do flash e a possibilidade de se obterem instantâneos, quanto dos meios cada vez mais

\footnotetext{
${ }^{3}$ Análise dos processos de transposição manual e fotomecânica e das tentativas de reprodução direta, a exemplo da fototipia e da autotipia, tal como entendidos na década de 1880, estão em Pinsard (1897). Para a trajetória da autotipia, ver: Gervais (2010, p. 1-25).
} 
eficiente de reprodução, ao que se somava a crescente valorização social da autenticidade e fidelidade, aportada tão somente pela representação em primeira mão, o que acabou por alterar sentidos e padrões vigentes na difusão da informação visual. Não por acaso, ao longo da década de 1890, multiplicaramse as publicações ancoradas na fotografia, a exemplo do The Illustrated America (Nova York, 1890) ou das francesas La vie au grand air (Paris, 1898) e La vie llustrée (Paris, 1898), maré montante que, no início do Novecentos, acabou por engolfar mesmo os mais renitentes e consolidou o modelo das revistas mundanas e de variedades, os chamados magazines (FEYEL, 2001), que se afirmaram como um dos ramos mais dinâmicos e importantes da imprensa ao longo de todo o século $\mathrm{XX}$.

No Brasil, a fototipia ${ }^{4}$ foi utilizada nos retratos publicados no semanário $O$ Álbum (RJ, 1893-1894), enquanto a prioridade, no que respeita à autotipia, coube, até onde se sabe, à segunda dentição da revista de Valentim Magalhães, $A$ Semana (RJ, 1893-1895), com dois retratos publicados em 1893, seguidos pelo de Assis Brasil, estampado em 1895 em A Cigarra (RJ, 1895-1896). Contudo, a efetiva disseminação da fotografia é unanimemente atribuída à longeva Revista da Semana (RJ, 1900-1959), lançada por Álvaro de Tefé e sempre saudada como um novo momento no periodismo ilustrado nacional (ANDRADE, 2004; FONSECA, 2016). À medida que avançavam as décadas iniciais do novo século, multiplicavam-se as revistas lançadas não só no Rio de Janeiro, mas também em várias outras capitais do país, impressos que igualmente apregoavam o colorido de suas páginas, as reportagens fotográficas sobre temas nacionais e estrangeiros, a diversidade de assuntos abordados, a excelência de seus colaboradores, o compromisso com a elegância e a última moda, o que explicita o sentido dos termos variedade e magazine, expressões da autorrepresentação almejada por seus responsáveis.

A crescente qualidade material dos periódicos atestava os investimentos realizados em máquinas e equipamentos e justificava a sempre reiterada promessa de assemelhar-se às congêneres impressas no exterior, tal como se

\footnotetext{
${ }^{4}$ Fototipia é o processo que reproduz o negativo fotográfico, em diferentes suportes, a partir das propriedades da gelatina bicromada. Trata-se de impressão planográfica e lenta, cuja matriz não suporta grande quantidade de cópias, daí seu uso restrito (PORTA, 1958).
} 
observa na apresentação da emblemática Kosmos. Revista artística, cientifica e literária (RJ, 1904-1909), que veio a público em janeiro de 1904 e cujo "formado grande $(31 \mathrm{~cm} \times 25 \mathrm{~cm}$ ), o papel couché, o uso intenso de cores nas capas e no interior, a fartura das ilustrações, a diagramação sofisticada", como precisou Dimas (1983, p. 5), atendiam às expectativas de um público exigente. Se, como fizeram questão de declarar seus editores, as dificuldades de produzir o impresso não eram pequenas, elas tampouco impediram que o projeto fosse levado a cabo no Rio de Janeiro. O rosário de títulos lançados e sua crescente segmentação, tendo em vista atingir públicos específicos, indica que as limitações técnicas, se não estavam ausentes, já podiam ser, ao menos, contornadas, o que instituia o início da modernidade tipográfica entre nós.

\section{Muito citada, pouco conhecida}

Foi nessa conjuntura que veio a público, em 1901, a Ilustração Brasileira. A decisão de imprimir o mensário na França sugere que nem todos estavam dispostos a enfrentar os empecilhos que cercavam a realização da empreitada no Rio de Janeiro, isso a despeito de já se contar, desde maio do ano anterior, com a circulação da Revista da Semana. Da Ilustração analisada são conhecidos doze números, compreendidos entre agosto de 1901 e julho de 1902, cabendo distingui-la das homônimas, uma impressa em São Paulo, entre 1903 e 1905 (CRUZ, 1997), e outra no Rio de Janeiro, entre 1909-1959, fundada por Luiz Bartolomeu de Souza e Silva e Antônio Azeredo e pertencente à Sociedade Anônima O Malho, ou seja, essas revistas não guardaram relação de continuidade com a congênere impressa no exterior. ${ }^{5}$

A Ilustração Brasileira em apreço é frequentemente mencionada ao lado dos muitos títulos lançados no alvorecer do século XX e caracterizada como integrante do grupo de publicações pioneiras no uso da fotografia, sem que se avance na análise sistemática do seu conteúdo. ${ }^{6}$ O fato não deixa de surpreender, sobretudo quando se leva em conta que o modelo revista ilustrada, destinado a

\footnotetext{
${ }^{5}$ Sodré (1999, p. 297), afirma: “Em 1901, aparecia também, mas em Paris, a Ilustração Brasileira, no modelo L'lllustration Française, morrendo em 1902, para ressurgir, agora no Rio, em janeiro de 1909", imprecisão reproduzida pela historiografia.

${ }^{6}$ As considerações mais detidas estão em Martins (2001, p. 88-89).
} 
público amplo, que se distinguia por abordar assuntos os mais variados e ancorar-se largamente no instantâneo fotográfico, marcou a imprensa (e não apenas a brasileira) ao longo de todo o Novecentos. Assim, investigar os primeiros ensaios levados a cabo entre nós é fundamental para compreender os caminhos que a produção e a difusão desse produto cultural complexo, que tenderá a se desdobrar para atender leitores cada vez mais específicos, trilhou.

O fato de imprimir a revista na França aponta em duas direções contrastantes. Isso porque, por um lado, tal decisão remetia ao passado, quando a excelência do produto em termos gráficos e a incorporação de imagens dependia, em larga medida, do que se produzia no exterior, o que justificava a busca de tipografias/clichês para além das fronteiras nacionais. De outra parte, porém, a revista incorporava justamente o avanço técnico que permitia registrar a realidade local e que garantiria o sucesso desse gênero de impresso periódico. Essa ambivalência impõe o desafio de tentar compreender a especificidade dessa Ilustração Brasileira, que não se esgota nos rótulos genéricos de inovadora/precursora que a historiografia the tem atribuído.

Não é simples, porém, ir além das generalidades, tendo em vista o espesso véu que encobre a revista. Assim, não é possível, apenas folheando os exemplares, esclarecer quem eram os responsáveis pelo projeto, pois a revista não trazia informações sobre proprietários, diretores ou editores. Brito Broca (2004, p. 298), ao destacar a ausência de dados, arriscou: "somos levados a atribuir a participação do Barão do Rio Branco na iniciativa, sobretudo pelo fato da revista ter deixado de circular em 1902, quando regressava ele ao Brasil para assumir a pasta do exterior," sem, contudo, adicionar qualquer outro elemento para apoiar sua hipótese.

A revista nunca indicou mais do que o mês de publicação, assim é impossível precisar o dia do lançamento de cada edição. Mas há indícios que sugerem que Broca pode ter razão. Quando o número inaugural veio a público (agosto de 1901), fazia quatro meses que Rio Branco estava instalado como representante do governo brasileiro em Berlim, cargo que the foi oferecido após seu desempenho na disputa que opôs o Brasil e a França na questão da fronteira 
com a Guiana.? Já o convite de Rodrigues Alves para que chefiasse o Ministério das Relações Exteriores chegou às suas mãos no início de julho de 1902 e, segundo revela sua volumosa correspondência, ele hesitou bastante em aceitálo, tendo finalmente cedido a 30 do mês seguinte. Rio Branco deixou a capital alemã em meados de novembro de 1902 e desembarcou no Rio de Janeiro em 1o de dezembro (CORRÊA, 2009). Não é improvável que o número de julho de 1902 da llustração já estivesse em preparação quando the foi proposto o novo cargo e tampouco the teria faltado tempo para envolver-se, no ano anterior, com o lançamento do periódico, tendo em vista que chegou à capital alemã nos primeiros dias de abril de 1901.

Entretanto, caso tenha existido relação de causa e efeito entre sua chegada em/partida de Berlim, não se trataria de simples participação, mas de empreendimento no qual ele teria desempenhado papel chave e, nesse caso, é sintomático que os muitos trabalhos que the foram consagrados não mencionem o fato. De toda forma, os elementos até aqui apresentados não corroboram, mas tampouco negam resolutamente, a suposição de Brito Broca, que adquire outros sentidos a partir da análise do conteúdo da publicação.

\section{Reatando fios}

A consulta à ficha catalográfica da Biblioteca Nacional, que informa como o impresso chegou à instituição, responsáveis, endereço, impressor, presença/ausência de encadernação, é prejudicada pois nela não se distingue entre a Ilustração Brasileira lançada em 1901 e a que circulou a partir de 1909, o que também se verifica no suporte digital, uma vez que as duas publicações foram disponibilizadas juntas, como se fossem um único periódico. Eis mais uma ressonância do pouco que se conhece a respeito da publicação, tanto que na Hemeroteca Digital Brasileira informa-se que a longeva Ilustração Brasileira, que circulou no Rio de Janeiro entre 1909 e 1958, era impressa na França. É somente

\footnotetext{
Sobre a disputa, cujo veredito saiu em 01/12/1900, ver: Jorge (1999, p. 53-79). Em relação às ideias políticas de Rio Branco, seu desempenho nas questões fronteiriças e no Ministério, ver: Santos (2012).
} 
graças aos Anais da Biblioteca Nacional que se pode afirmar que a instituição mantinha assinatura do mensário que circulou entre 1901 e $1902 .^{8}$

Todos os exemplares da Ilustração Brasileira estamparam dois endereços, para os quais a correspondência deveria ser remetida: um em Bordeaux, Rue Tourat n. 40, enquanto a redação e a administração localizavam-se em Paris, Rue de la Victoire n. 48. No que respeita à impressão, na última página numerada de cada exemplar lê-se: “G. Delmas, Imprensa editora da Ilustração Brasileira, Rue de la Victoire, 48. Gerente Júlio Parquet". O dado não é isento de controvérsias, pois é possível supor que o endereço da revista em Paris também fosse o da tipografia, o que não era raro no período, enquanto o cargo de gerente poderia dizer respeito à /lustração ou à tipografia.

Contudo, é muito provável que o impressor fosse Gabriel Delmas (18601942), cuja família residia em Bordeaux e estava no ramo gráfico desde 1849. Ele assumiu a empresa em 1888, oportunidade em que a transferiu da Rue SaintCatharine n. 139, para a Rue Saint-Christoly n. 10, onde permaneceu muito tempo depois de a revista ter deixado de circular, ${ }^{9}$ ou seja, o endereço da Ilustração Brasileira em Bordeaux não se confundia com o do impressor. Produzir a revista numa cidade portuária evitava o custo do transporte e o tempo gasto no percurso, caso a impressão ocorresse em Paris. Acerca de Júlio Parquet, cuja grafia do prenome remete para o português e a do sobrenome para o francês, não foi possível obter informações, ainda que seja muito provável que seu cargo dissesse respeito à revista e não ao impressor.

Tampouco há dados, diretos ou indiretos, sobre a tiragem e a origem dos recursos financeiros, exceção feita à página dedicada aos anúncios, idêntica em todos os exemplares e na qual o uso de iconografia era modesto, o que colaborava para a monotonia do conjunto. Predominavam empresas da região de Bordeaux (sete contra uma de Paris e uma do Rio de Janeiro), indício de que a representação da revista nessa cidade deveria ser bastante ativa. Havia anúncios de bebidas, manteiga, vermífugo e hotéis, todos de Bordeaux ou proximidades;

\footnotetext{
8 Título citado entre as recebidos por subscrição em 1902: Anais da Biblioteca Nacional (1903, p. 333). Registre-se a condenável política de interditar a consulta, no suporte papel, dos títulos digitalizados.

${ }^{9}$ Acerca das atividades da família Delmas, ver: Bouchon (1901).
} 
perfumes e chapéus de Paris e a Companhia das Loterias Nacionais do Brasil, como se vê na figura 1. A publicidade estava alocada em página do invólucro que acompanhava cada exemplar, proteção que parece ter sido bastante disseminada entre os periódicos ilustrados do Oitocentos, mas que raramente foi preservada. É preciso ter em vista que esses impressos, caracterizados pela efemeridade, ansiavam desfrutar da nobilitação reservada aos livros, tanto que apresentavam numeração sequencial e incentivavam os leitores a encadernarem os exemplares, o que resultava, no mais das vezes, no descarte da proteção, que perturbava a aparência livresca do conjunto.

A /lustração Brasileira não completou um ano de vida, mas também adotou a paginação contínua. Esse detalhe é relevante na medida em que aponta para práticas vigentes no século que acabara de findar, ou seja, seus responsáveis ainda se pautavam pela noção de que os impressos periódicos ilustrados mereciam ser guardados e, portanto, subscreviam a ideia de que o seu consumo não se esgotava na leitura, percepção que, no Brasil, continuou vigente pelo menos ao longo da primeira década do século XX, como indica o exemplo da Revista da Semana, aferrada à paginação contínua até meados de 1909.

Importa destacar que, na coleção da Biblioteca Nacional, as quatro páginas não numeradas e que acompanharam cada exemplar estão disponíveis, o que pode ser atribuído ao fato de a terceira página conter o índice do número, informação que dificilmente poderia ser considerada sem importância e à qual se pode atribuir a preservação do invólucro. Esse, por sua vez, era constituído pela página de abertura, cujo cabeçalho exibia imagem que remetia ao Rio de Janeiro, enquanto o restante era tomado pelo mapa do país, rodeado por alusões aos produtos da terra, como o café e a cana-de-açúcar, e cujo enquadramento evocava o Brasão da República, ao que se somam duas figuras, uma masculina e outra feminina que remetiam a ação e a fala, respectivamente. O verso era ocupado pelos reclames, enquanto na página três figurava o sumário, com distinção entre textos e gravuras e, por fim, a quarta e última trazia dados relativos ao expediente. Tratava-se, portanto, sempre do mesmo conjunto, com a óbvia exceção do sumário, dos dados da edição no cabeçalho e de pequenas variações no expediente (Figura 1). 
Ilustração Brasileira (Bordeaux/Paris, 1901-1902): em busca do projeto e de seus idealizadores Tania Regina de Luca

Figura 1 - Quatro páginas que envolviam cada edição da Ilustração Brasileira
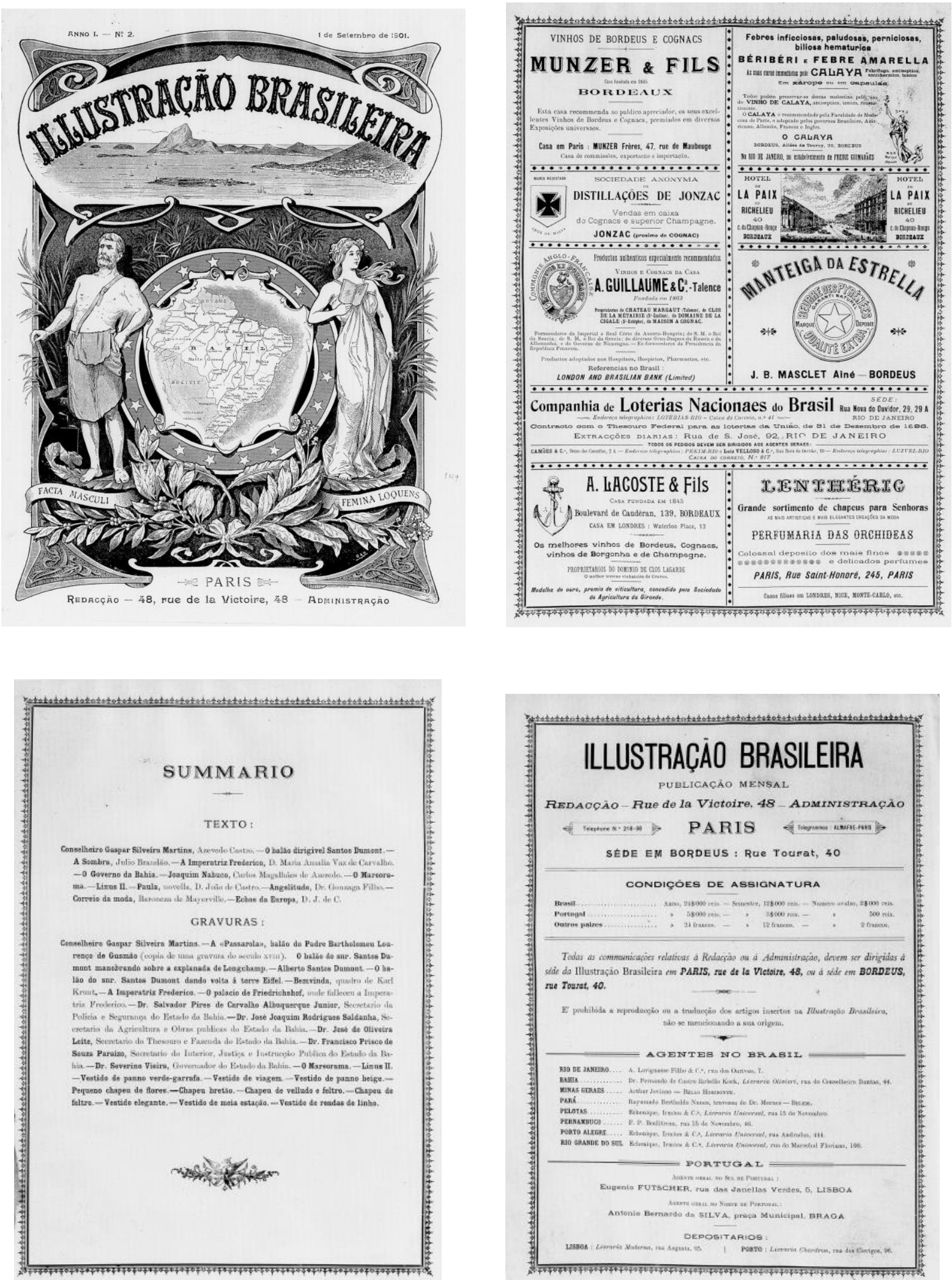

Fonte: ILUSTRAÇÃO BRASILEIRA, 1901a, invólucro. Hemeroteca Digital da Biblioteca Nacional. 
Outro dado a considerar, presente apenas na contracapa do invólucro, é o preço. A /lustração previa assinatura anual e semestral, além de venda avulsa no Brasil (24\$000, 12\$000 e 2\$000 e, da sétima edição em diante, 2\$500 réis), em Portugal (5\$000, 3\$000 e 500 réis) e nos demais países, (24, 12 e 2 francos), dados que isolados, pouco esclarecem. Na mesma época, os preços da Illustration (36 e 18 francos e 75 centavos) e do Le Mondé Illustré (26 e 13 francos e 50 centavos) eram menores, pois há que se considerar que as francesas tinham 16 páginas e circulavam semanalmente, enquanto a llustração, com 24 páginas por número, era mensal. A diferença, em termos de valores, tornava-se ainda mais pronunciada em face do periódico O Ocidente. Revista ilustrada de Portugal e do estrangeiro (Lisboa, 1878), com três edições mensais de 8 páginas cada (3\$800, 1 \$900 e \$120 réis), e da Revista da Semana quando de seu lançamento em 1900, também com 8 páginas por exemplar (15\$000, 8\$000 e 300 réis). Vê-se, portanto, que não se repetiu o padrão observado com $A$ llustração, antecessora impressa em Paris entre 1884 e 1892 e vendida, a despeito de sua sofisticação gráfica, por valores modestos em relação aos então vigentes no Brasil e em Portugal.

Apesar de estabelecer preços para outros países, a quarta página do invólucro contém indicações relativas somente ao Brasil e a Portugal. Esse último país contou, até a nona edição, com representante no Sul (Eugenio Futscher, Rua da Janelas Verdes n. 5, Lisboa) e no Norte (Antonio Bernardo da Silva, Praça Municipal, Braga), além de ter como depositários a Livraria Moderna, Rua Augusta n. 95, na capital, e a famosa Livraria Chardron, Rua dos Clérigos n. 96, no Porto. Nos três últimos números, por sua vez, desaparecem os representantes regionais e ambas as funções ficaram a cargo das livrarias.

Para o Brasil, há indicação de agentes, ora para cidades, ora para Estados, sem que se mencione São Paulo, então uma das regiões mais dinâmicas do país em termos econômicos. O Rio de Janeiro, por sua vez, nem sempre foi referido e chama atenção que um indivíduo tenha substituído a tradicional Casa Lombaerts que, com a morte de Henri Gustave Lombaerts (1897), adotou o nome do sócio, Alexandre Lavignasse Filho \& Cia. Os dados reunidos na tabela 1 revelam endereços incompletos e até a falta dos mesmos, como se vê para Belo Horizonte, o que coloca dúvidas quanto à eficácia desses agentes. 
Tabela 1 - Agentes no Brasil da Ilustração Brasileira

\begin{tabular}{|c|c|c|}
\hline Local & Nome/Endereço/Edição & Total \\
\hline Bahia & $\begin{array}{l}\text { Dr. Fernando de Castro Rebello Kock, Livraria Olivieri, } \\
\text { Rua Conselheiro Dantas, } 44 \text {. (1 ao 9) } \\
\text { Viúva Kock e filhos (10 ao 12) }\end{array}$ & 12 \\
\hline Minas Gerais & Arthur Joviano, Belo Horizonte & 12 \\
\hline Pará & $\begin{array}{l}\text { Raymundo Bertholdo Nunes, Travessa do Dr. Moraes, } \\
\text { Belém }\end{array}$ & 12 \\
\hline Pernambuco & $\begin{array}{l}\text { F. P. Boulitreau, Rua } 15 \text { de Novembro, } 46 \text { (1 ao 5) } \\
\text { Tondella, Cockles \& Cia, Rua } 15 \text { de Novembro } 46 \text { (6 e 7) } \\
\text { Dr. Apolinário da Trindade M. Henriques, Estrada de João } \\
\text { de Barros, 11, Recife (8 ao 12) }\end{array}$ & 12 \\
\hline Pelotas & $\begin{array}{l}\text { Echenique, Irmãos \& C. a , Livraria Universal, rua } 15 \text { de } \\
\text { Novembro* }\end{array}$ & 12 \\
\hline Porto Alegre & $\begin{array}{l}\text { Echenique, Irmãos \& C. } . \text {, Livraria Universal, rua Andradas } \\
444\end{array}$ & 12 \\
\hline $\begin{array}{l}\text { Rio Grande } \\
\text { do Sul }\end{array}$ & $\begin{array}{l}\text { Echenique, Irmãos \& C. } . \text {, Livraria Universal, rua Marechal } \\
\text { Floriano, } 106\end{array}$ & 12 \\
\hline $\begin{array}{l}\text { Rio de } \\
\text { Janeiro }\end{array}$ & $\begin{array}{l}\text { A. Lavignasse Filho \& C. a, Rua dos Ourives, } 7 \text { ( } 2 \text { e 3) } \\
\text { Dr. M. J. Valdetaro, Rua do Rosário, 64-1o (6 ao 12) }\end{array}$ & 09 \\
\hline Alagoas & Francino \& Filho, Rua do Comércio, Maceió (7 ao 12) & 06 \\
\hline Sergipe & Augusto Gomes, Praça 7 de Setembro, Estância (7 ao 12) & 06 \\
\hline Amazonas & Lino Aguiar \& Cia, Rua Municipal, 95, Manaus (8 ao 12) & 05 \\
\hline Paraíba & Antonio Penna \& Cia (8 ao 12) & 05 \\
\hline
\end{tabular}

Fonte: Elaborada pela autora, 2020.

No início do século XX, as páginas dos jornais e revistas ainda registravam a chegada às redações de títulos recém-lançados ou de novas edições, o que também ocorreu com a llustração Brasileira. A revista foi distinguida com notas sucintas, o mais das vezes relativas aos números iniciais. Com exceção de duas folhas do Recife, que agradeceram explicitamente o representante local pelo envio de exemplares (A PRIMAVERA, 1902, p. 2), ${ }^{10}$ as demais alusões à publicação ficaram restritas a periódicos do Rio de Janeiro, cabendo sempre ressalvar que

\footnotetext{
${ }^{10}$ As referências mais tardias, relativas aos números 7 e 9, estão citadas no Diário de Pernambuco (SUMÁRIO DA IMPRENSA. Diário de Pernambuco, Pernambuco, ano 78, n. 41, p. 2, 20 fev. 1902. Disponível em: http://memoria.bn.br/DocReader/029033_08/3216. Acesso em: 11 ago. 2020; 
a pesquisa, realizada na Hemeroteca Digital, nunca fornece resultados absolutos, tanto pelas limitações do motor de busca quanto pelo fato de a coleção seguir incorporando novos títulos.

Mas mesmo pequenas notas revelam surpresas, a começar pelo fato de Lavignasse apresentar-se como agente desde o lançamento, a despeito de sua empresa não figurar no primeiro número, como se lê no registro de Eloy, o herói (pseudônimo de Artur Azevedo), estampado em A Estação. Jornal Ilustrado para a família (RJ, 1879-1904), que ainda mencionou o responsável pela direção, informação que o mesmo cronista também publicou em O País (RJ, 1884-1889):

Também de Paris recebi o 1o número da /lustração Brasileira, que ali se publica sob a direção do Sr. Sully de Souza, e se recomenda tanto pelo texto como pelas gravuras. São agentes da Ilustração Brasileira nesta capital os Srs. A. Lavignasse Filho \& C., proprietário da Estação, que não me levarão a mal o réclame. (ELOY, 1901, p. 100) $)^{11}$

É tentador supor que, por colaborar em revista de propriedade do agente da Ilustração Brasileira no Rio de Janeiro, Azevedo tivesse informações privilegiadas, o que não parece ter sido o caso, pois o nome do diretor figurou, com dias de antecedência, em O Fluminense (ILUSTRAÇÃO..., 1901b, p. 1).

Nas páginas da revista, Sully de Souza foi mencionado em duas oportunidades: na quinta edição, quando Gonzaga Filho referiu-se a ele como o colega que the pediu colaboração, e na oitava, bem mais explícita, quando outro colaborador, Tillement Fontes, identificou-o como diretor da publicação e cônsul brasileiro em Bordeaux. De fato, a essa altura, Sully José de Souza já acumulava longa experiência, pois estava na diplomacia pelo menos desde meados da década de 1880, tendo ocupado diversos cargos, entre eles o de cônsul em Frankfurt, onde permaneceu entre 1887 e 1895, passando por Trieste (1896) e Bordeaux (de 1898 a 1908), ${ }^{12}$ ou seja, se não é possível vincular diretamente a revista ao Barão do Rio Branco, ao que parece, ela gravitava em torno do corpo diplomático brasileiro. Apesar de a redação e a administração localizarem-se em

\footnotetext{
${ }^{11} \mathrm{O}$ mesmo autor repetiu a informação, assinando com as suas iniciais, em outra ocorrência (A. A., 1901, p. 1).

12 Para os cargos que ocupou entre 1891 e 1908, consultar os números correspondentes a esses anos do Almanaque administrativo, mercantil e industrial do Rio de Janeiro (RJ, 1891-1940), conhecido como Almanaque Laemmert.
} 
Paris, tudo parece indicar que a maior parte das atividades se concentrava em Bordeaux: direção, obtenção de anunciantes, impressão, trabalho de remessa para o Brasil.

\section{Por dentro da llustração}

Para desvendar os objetivos da publicação, conta-se com a breve apresentação do primeiro número, que logo de saída evocou a "nobre e simpática tentativa" de estreitar as relações intelectuais entre o velho e o novo mundo. Esse amplo propósito ganhou contornos um pouco mais precisos graças à explicitação das características do periódico:

Afastando paixões de toda a espécie, polêmicas estéreis e irritantes, só procuraremos acompanhar, como cronistas cuidados e conscienciosos, o desenvolvimento da nossa pátria, historiando os seus progressos, registrando as suas glórias, arquivando a memória dos seus homens ilustres de todos os tempos, documentando enfim, de uma maneira clara e interessante, o importantíssimo período de transformação que o Brasil agora atravessa. (ILUSTRAÇÃO..., 1901a, p. 02).

Sobressai o tom patriótico e ufanista, tanto que os responsáveis pela publicação, adjetivada de brasileira, não duvidavam dos avanços alcançados pelo país; antes propunham-se a divulgá-los e a constituir uma galeria de indivíduos ilustres, do passado e do presente, espécie de reserva moral da nação. A revista, além de "clara e interessante", prometeu "primorosa seleção de colaborações e assuntos" e elencou temáticas relacionadas às "ciências, artes e indústrias modernas" (ILUSTRAÇÃO..., 1901a, p. 02), tidas como fatores essenciais para a civilização e o progresso, subscrevendo o discurso positivista então em voga e que a publicação ajudou a difundir. Asseverou, ainda, que suas páginas trariam contribuições originais de iminentes escritores luso-brasileiros e, em sintonia com a proposta típica dos magazines de variedades, aspirava agradar diferentes públicos: "nem só às severas e exigentes curiosidades masculinas satisfaremos; a mulher e a criança terão igualmente o seu quinhão na partilha da nossa revista: uma ampla seção de modas”, com a pronta reprodução dos últimos modelos de Paris (ILUSTRAÇÃO..., 1901a, p. 02). Tal divisão, que contrapunha a seriedade dos interesses masculinos à futilidade feminina e infantil, subscrevia a percepção 
então dominante em relação aos gêneros e idades e reafirmava valores sociais expressos nas imagens da capa do invólucro (Figura 1). Assim, a despeito de também visar a leitora, predominava, numa revista feita por e dirigida sobretudo para homens, a reafirmação do lugar social então consagrado às mulheres. Digna de nota é a ausência de qualquer outra menção às estampas e fotografias, que obviamente não se restringiam à parte dedicada à moda, uma vez que o periódico reivindicava a condição de ilustrado.

Programas indicam intenções, cuja efetividade também se expressa na organização interna do conteúdo. No caso da /lustração Brasileira, observa-se padrão fixo de ordenação e em sintonia com as declarações da apresentação. Assim, a capa de cada número era tomada por imagem de políticos e/ou militares brasileiros, acompanhada de texto alusivo aos seus feitos. Seguia-se um conjunto diversificado de artigos, que tanto poderia incluir alongados ensaios que ocupavam várias páginas e mesmo números, ou notas curtas, muitas vezes sem indicar autoria, o que remete para a atuação do(s) redator(es), fosse para selecionar material a ser reproduzido de outras fontes ou para produzi-lo. Como anunciado no programa, todas as edições estampavam produção literária, ao que se somava duas seções fixas, "Correio da Moda" e "Ecos da Europa". A revista continha muitas imagens, tanto isoladas quanto articuladas a conteúdos textuais.

A elegante diagramação mobilizava diversas famílias de tipos, cujas letras variavam em dimensões e espaçamentos; valia-se de negritos, especialmente nos títulos; além de elaboradas capitulares. Delicados filetes, florões e ornatos tipográficos, contendo ora motivos geométricos ora florais, delimitavam visualmente os conteúdos. Por vezes, a largura das duas colunas que compunham cada página aumentava, diminuía e mesmo poderia ser totalmente subvertida para acomodar recortes não lineares da iconografia, o que colaborava para dar ao conjunto a sensação de movimento e dinamicidade. Aliás, é patente a preocupação, particularmente bem-sucedida nos artigos mais longos, de promover o diálogo entre texto e iconografia, o que nem sempre se verifica quando uma ou várias imagens acompanhavam novas curtas, ocasiões em que o leitor as encontrava antes ou depois da notícia, mescladas a assuntos que não lhes diziam respeito. Já no que respeita às imagens avulsas, ou seja, que não 
eram acompanhadas por textos, elas nem sempre ocupavam uma página inteira e, nessas ocasiões, sua localização na página respondia unicamente aos imperativos da diagramação. ${ }^{13}$

Para preencher eventuais espaços vazios, recorria-se a frases ou parágrafos, material identificado no índice pelos títulos "Fragmentos", "Pensamentos" ou "Pedras soltas". A seleção recaia em escritores célebres de diferentes épocas e não visava entreter ou divertir, mas fornecer máximas sobre a nação, o progresso, valores éticos e morais, o que é um indício das expectativas dos responsáveis em relação ao público leitor. Recorreu-se ao brasileiro Marques de Maricá, ao francês Victor Hugo e aos portugueses Bernardim Ribeiro, Frei Heitor Pinto, Padre Antônio Vieira, Visconde de Ouguela, Eça de Queirós e Ramalho Ortigão, único então vivo dentre os escolhidos. ${ }^{14}$

O Brasil fazia-se presente nas páginas da revista de diferentes formas, a começar pela capa, sempre integralmente tomada por uma figura pública, como se vê na relativa ao número inaugural, que estampou o retrato de Campos Sales, então presidente da República. Os três personagens subsequentes ainda viviam - Joaquim Nabuco, Conselheiro Gaspar Silveira Martins e Marechal João Thomaz de Cantuária - mas todos os demais, citados na ordem em que figuraram na publicação, já haviam falecido - Zacarias de Góes, Barão de Cotegipe, Almirante Barroso, Conselheiro José Bonifácio, Marques de Herval, Almirante Tamandaré, Conselheiro Paulino José de Souza e o Conde de Porto Alegre. Tratava-se de homens públicos, a maioria com atuação no Segundo Império, vários deles integrantes das forças armadas e com participação ativa na Guerra do Paraguai, cabendo notar a ausência da liderança responsável pela mudança do regime. Imediatamente após a capa, seguia-se artigo circunstanciado sobre a vida e os feitos dos homenageados, cinco dos quais não assinados, enquanto dos sete

\footnotetext{
${ }^{13}$ A título de exemplo, as fotos relativas ao acidente de Santos Dumont na Bahia Monte Carlo antecederam a nota sobre o fato e foram estampadas em meio à biografia do Marques de Herval (O NAUFRÁGIO..., 1902, p. 197-198). Nessa mesma edição, há imagem do porto de Bordeaux em meio a artigo sobre febre amarela e travessia a nado das Cataratas do Niágara (FRANÇA, 1902, p. 208).

${ }^{4}$ Eis alguns exemplos: "Na ciência, o estudo comparativo das sociedades é o que mais seguramente conduz ao conhecimento das leis do progresso" (ORTIGÃO, 1901, p. 41); "A virtude tem um véu, o vício tem uma máscara" (HUGO, 1902, p. 150); "Os homens que não se vingam são sempre os mais bem vingados" (MARICÁ, 1902, p. 247).
} 
restantes, apenas dois não foram escritos por integrantes do corpo diplomático brasileiro. ${ }^{15}$ Nesse aspecto, a revista afastava-se das congêneres ilustradas, que se esmeravam em ofertar capas atraentes e coloridas, sempre privilegiando novidades do momento, ou seja, a revista estava a meio caminho entre o compromisso com novidade e a informação, pedra de toque do gênero periódico ilustrado, e a preocupação em formar o seu leitor.

O inventário de nomes célebres não se restringia às primeiras páginas, antes espraiava-se pelo interior das edições, sempre respeitando o mesmo padrão das capas: textos acompanhados dos respectivos retratos, porém sem a preocupação de fornecer data, nome do fotógrafo ou do autor do desenho, gravador ou responsável pela produção das matrizes para impressão. O critério de escolha dos nomes também continuava o mesmo: homens de destaque no âmbito do poder. Assim, reverenciavam-se indivíduos vivos, que já haviam ocupado ou exerciam a chefia do executivo estadual - caso de Francisco Silvano de Almeida Brandão (MG), Conselheiro Antônio Gonçalves Ferreira (PE), Borges de Medeiros e Júlio de Castilhos (RS) -, com especial destaque para toda a administração da Bahia, na pessoa de Severino Vieira e seu secretariado.

A esses somavam-se políticos (Barão de Marajó), militares da ativa (os generais João da Silva Barbosa e João Nunes da Silva) ou já falecidos (Barão do Triunfo, General Carlos Maria da Silva Teles), além dos diplomatas José da Silva Paranhos, pai e filho. O rol indica que memória acerca do país se desejava "arquivar", para retomar os termos do artigo de apresentação, assim como colaborar para traçar o perfil do público que se pretendia atingir.

A grande maioria desses escritos não era autógrafo, exceção feita a três, um dedicado aos Silva Paranhos, pai e filho, da lavra de Domício da Gama, então trabalhando na legação brasileira em Londres; outro ao Presidente do Estado de Pernambuco, assinado pelo professor da Faculdade de Direito do Recife, Júlio

\footnotetext{
${ }^{15}$ Não assinados: Campos Sales, Cantuária, Bonifácio, Herval e Porto Alegre. Carlos Magalhães de Azeredo, da legação brasileira na Santa Sé, tratou de Nabuco; José Antônio de Azevedo Castro, delegado do Tesouro Nacional em Londres, escreveu sobre Silveira Martins; Dr. Gonzaga Filho, com posto em Glasgow, encarregou-se de Zacarias de Góes; Rio Branco, ministro em Berlim, biografou o Barão de Cotegipe; o tenente João Augusto dos Santos Porto discorreu a respeito do Almirante Barroso; Henrique Carlos Ribeiro Lisboa, com cargo em São Petersburgo, referiuse ao Almirante Tamandaré e, por fim, o Barão Homem de Melo, monarquista convicto, discorreu sobre o Conselheiro Paulino.
} 
Pires Ferreira Sobrinho, e, por fim, o de João da Silva Barbosa, de autoria do Professor da Faculdade de Medicina da Bahia, Tillemont Fontes. Apenas dois escritores, ambos falecidos, figuraram nesse panteão: Gonçalves Dias e José de Alencar e, ainda assim, por meio de pequenas notas, a primeira de Olavo Bilac e a segunda transcrita da revista portuguesa O Ocidente.

Registre-se, ainda, a presença de retratos acompanhados apenas de legenda informando o nome e o cargo ocupado, como se observa na sua última edição, que trouxe página com os bustos dos chefes do executivo do Amazonas, Pará, Maranhão, Rio Grande do Norte e Goiás, enquanto que membros da diplomacia brasileira foram retratado na sétima - Gabriel de Toledo Pizza (Paris), Francisco Regis de Oliveira (Viena), Henrique Carlos Ribeiro Lisboa (São Petersburgo) e Pedro de Araújo Brandão (Madri) - e na décima primeira edições - A. de Moraes Gomes Ferreira (Paris), Alfredo Leite Rodrigues Torres (Lisboa), J. Fausto de Aguiar (Berlim), J. M. Cardoso de Oliveira (Londres).

No que diz respeito aos nomes ligados ao mundo da intelectual e cultural, consta uma única foto, tirada quando Lúcio de Mendonça foi homenageado pelo lançamento do livro Horas do bom tempo, evento que reuniu seleto grupo de escritores e artistas. Fica evidente, portanto, que a escolha recaía em vultos do mundo da política, biografados, em grande parte, por membros do corpo diplomático, o que permite compreender a suposição de Brito Broca, que associou a llustração ao Barão do Rio Branco.

As considerações apresentadas indicam que a proposta da llustração Brasileira não respondia plenamente aos protocolos típicos das revistas ilustradas. Não resta dúvida que essas também abrigavam em suas páginas personalidades em evidência, fosse do mundo da política, economia, cultura, esportes ou ciências, como também evocavam personagens históricos, desde que fossem relevantes para a compreensão de fatos ou eventos em curso. A diferença residia tanto nas motivações para as escolhas da Ilustração quanto na abordagem. Compor uma galeria de exemplos heroicos, a ser compartilhada com os leitores de modo a atestar o valor moral dos construtores e dirigentes da nação, demandava textos analíticos, com circunstanciada análise da trajetória do indivíduo, suas realizações e valorosas contribuições para os destinos do país, o 
que igualmente se aplicava para os que estavam em plena atividade, a exemplo do Presidente Campos Sales.

Havia, pelo menos no que respeita a esse conteúdo, resquícios que remetiam a modelos anteriores de impressos periódicos, cujo compromisso era menos o aqui e o agora, a notícia e a atualidade, do que os intuitos pedagógicos de instruir, educar e formar, sem esquecer que todo processo de arquivamento é dotado de intencionalidades e impõe apagamentos (DERRIDA, 2001), aqui em relação ao que (não) deveria integrar a memória histórica nacional. Ainda uma vez, cabe insistir na ambiguidade do projeto da llustração Brasileira, que transitava entre rotinas e convenções e a sedução das novas possibilidades abertas pela fotografia. Noutros termos, o fato de um impresso mobilizar as mais modernas técnicas disponíveis não significa, necessariamente, que as utilize de modo a delas extrair todas as consequências. Compreende-se, portanto, a limitação de se arrolar essa ilustração ao lado de outras publicações contemporâneas simplesmente pelo fato de também estampar fotografias, sem levar em conta que os títulos se pautavam por práxis diversas.

Em relação aos não brasileiros, os parâmetros eram diversos, pois, nesses casos, a revista aproximava-se do ideal de dar conta da atualidade. Assim, a Ilustração Brasileira não se furtou a abrir espaço para personalidades recémfalecidas - a Rainha Vitória; sua filha mais velha, cujo marido ocupou por breve período o trono alemão; o presidente dos Estados Unidos, William Mac-Kenley; a sobrinha de Napoleão Bonaparte, conhecida por Princesa Rattazzi -, mas também para o rumoroso assassinato do Czar Alexandre II ocorrido em 1881.

Bastidores pouco conhecidos, como um projetado encontro entre Bismarck e Gambetta, ou a descrição de uma missa celebrada pelo Papa Leão XIII, ocuparam as páginas da revista, assim como a francesa Jeanne Chauvin, primeira mulher a obter diploma de Direito no seu país, o que figurava no campo das curiosidades, sem que implicasse na defesa do direito da mulher à instrução, aliás como se fez questão de se frisar no texto que apresentou a personagem. É inegável que havia compromisso com eventos recentes, mas eles não davam o tom e, quando presentes, o tratamento não se limitava aos aspectos superficiais. Assim, por exemplo, no caso da morte da Rainha Vitória, o foco não recaiu apenas na soberana, mas também na conjuntura política que cercava o início do reinado 
de Eduardo VII, razão pela qual ao retrato da soberana somavam-se os de outras figuras de proa da política inglesa.

A autoria desses textos é um ponto importante, mas é difícil estabelecer a sua procedência: teriam sido preparados especialmente para a llustração? Alguns, escritos por nomes então bastante conhecidos, eram transcrições cujas fontes foram especificadas, restando saber se, em outros casos, o dado não foi mencionado para sugerir ao leitor que se tratava de inéditos, tal como prometido no texto de apresentação. De toda forma, persistiu a tendência, já manifesta, de privilegiar colaboradores do mundo da diplomacia, entretanto, desta feita, não foram mencionados brasileiros, o que implicava em significativo trabalho de tradução, mesmo que os textos tivessem sido escritos expressamente para a revista, o que parece pouco provável. ${ }^{16}$

O conteúdo internacional priorizou indivíduos e reservou pouco espaço para o candente tema das disputas entre as potências europeias, acirradas pela corrida colonial. Na revista, há apenas dois artigos, sem assinatura mas devidamente ilustrados, sobre a luta dos habitantes do Transvaal (África do Sul) contra o Império Britânico e outro com descrição dos hábitos e costumes do Sião, o que pode ser interpretado como uma forma de não tomar posição diante do complicado jogo de alianças europeias. Os Estados Unidos, por sua vez, só compareceram em função da morte do seu presidente.

Fazendo jus ao título, a revista estampou várias vistas do Brasil, a grande maioria composta por fotografias que privilegiavam o espaço urbano em detrimento da exuberante (e sempre evocada) paisagem natural, escolha não inocente e que cumpria a função de atestar o quanto o país estava em sintonia com a modernidade e o progresso. O destaque ficou por conta do Rio de Janeiro, presente em seis números, seguido por Salvador (em duas edições), Vitória, Porto

\footnotetext{
${ }^{16}$ Reginald Mac-Kenna, figura de proa da política britânica, analisou o contexto do país após a morte da Rainha Vitória em texto transcrito da Revue Politique et Parlamentaire (Paris, 1894); o cônsul norte-americano na França, Albion W. Tourgée, avaliou a presidência de Mac-Kinley; o ex-diplomata francês Eugène-Melchior de Vogüé, conhecedor da Rússia, discorreu sobre o czar assassinado, em artigo transcrito de Les Annales politiques et littéraires (Paris, 1883); o político e escritor francês Emmanuelle Arène, próximo de Gambetta, comentou o malfadado encontro; o também francês e escritor Jean Accard referiu-se a Leão XIII; a escritora portuguesa Maria Amália Vaz de Carvalho detalhou os infortúnios da esposa de Frederico Guilherme; J de Sequeiros e Abreu, acerca de quem não se tem informações, além do fato de ser português, tratou da sobrinha de Bonaparte; enquanto o artigo sobre Chauvin não indicou autoria. Observese que apenas dois dos colaboradores identificados eram lusófonos.
} 
Alegre, Pelotas e a Cachoeira de Teotônio no rio Madeira (uma vez cada), essa a única não tocada pela ação humana. Note-se que as fotografias (e as poucas estampas) eram acompanhadas por breve identificação geográfica e, ainda uma vez, sem indicar data, procedência e autoria das mesmas. ${ }^{17}$

A esse rol somavam-se outras relativas à Lisboa (uma ocorrência) e um montante para a França que ultrapassou, em termos quantitativos, as relativas ao Brasil: duas estampas da ponte Alexandre III, inaugurada para a Exposição de 1900, fotografias de Castres (uma), Bordeaux (três) e mais de uma dezena de instantâneos de Lion, Avignon e cidades dos arredores, e da região dos Pirineus na fronteira com a Espanha, cada uma das séries ocupando duas páginas inteiras. Compreende-se a forte presença do Hexágono, seja por simbolizar o ideal de civilização e modernidade tão perseguido pela elite brasileira, seja pela relativa facilidade de obter material, em função de ser impressa por empresa francesa.

Ainda que possa resultar de mera coincidência, vale destacar que, em duas oportunidades, cidades brasileiras e francesas dividiram a página: o Rio de Janeiro e Bordeaux (n. 4), Castres e Vitória (n. 11), o que obviamente convidava o leitor a estabelecer comparações. Observe-se que as escolhas nunca recaíram no registro do cotidiano das cidades, seu burburinho e personagens, mas em tomadas distanciadas, que excluíam a presença de indivíduos e acabavam por privilegiar edificações. ${ }^{18}$ Pode-se afirmar que esse material, que tanto poderia ocupar uma página inteira ou figurar ao lado de textos com os quais não guardava qualquer relação, também cumpria a função de entreter e distrair, dando sentido à noção de folhear a revista, aspecto que aproximava a llustração Brasileira dos magazines ilustrados que se multiplicaram a partir do início do século XX e aponta, novamente, a dupla face da publicação.

Tal como prometido no programa, a publicação também incluiu, em todos os seus números, notas sobre as realizações "das ciências, artes e indústrias

\footnotetext{
7 Foram localizadas duas fotos: na edição inaugural a Praia da Saudade (RJ), de Juan Gutierrez, datada dos anos 1890 e pertencente ao Arquivo Nacional, e, na nona edição, o Elevador da Conceição (atual Lacerda), de Rodolfo Lindemann, tomada em meados da década de 1880 e pertencente ao Instituto Moreira Salles.

${ }^{18} \mathrm{~A}$ exceção fica por conta das fotos relativas à pequena comuna (Elne, Fontpédrouse, Prats-deMollo-La-Preste), que flagram os habitantes de vida simples, numa perspectiva próxima do exótico.
} 
modernas", devidamente ilustradas, fosse por fotos ou desenhos, em sintonia com o orgulho positivista frente aos avanços da civilização e do progresso. E, mais uma vez, cabe destacar que a grande maioria dos artigos, com dimensões variadas (de alguns parágrafos a várias páginas), não trazia assinatura, ou seja, havia um trabalho de busca, seleção, ordenação, tradução e mesmo reescrita por parte da redação, configurando atos editoriais, inclusive no que respeita ao material iconográfico.

A título de exemplo, pode-se citar novidades como o eletroímã, utilizado para retirar metais dos olhos; o tratamento para os desvios na coluna, colaboração do médico de Bordeaux Joseph Gourdon; ou o estudo sobre os mosquitos e a febre amarela, de autoria do brasileiro Hilário de Gouvêa, que se estendeu por cinco edições e evidenciava a participação do país nos debates médicos. As pesquisas de Marconi sobre o telégrafo sem fio, o aparelho de telegrafia rápida dos húngaros Pollak e Virág, a construção de potentes telescópios, experiências com a eletricidade, ou os avanços em relação ao controle do clima eram tratados em detalhes e objetivavam esclarecer os princípios científicos envolvidos nessas realizações, o que pressupunha um leitor minimamente familiarizado - e interessado - em minudências.

Os avanços no campo dos transportes receberam particular atenção, fossem os automóveis, as inovações nos navios e submarinos, a conquista do ar. Sempre que possível, abria-se espaço para o Brasil e a Marinha, então em plena renovação de sua frota, foi contemplada com imponente foto de página inteira do couraçado Riachuelo, detida descrição do Couraçado Floriano, lançado ao mar em 1899, acompanhada da biografia de seu comandante, Duarte Huett Bacelar Pinto Guedes, ambos não assinados. Adicione-se a apresentação do submarino desenhado pelo engenheiro e ex-tenente da Marinha, Luís de Mello Marques, ou a descrição dos esforços, no campo da aviação, levadas a efeito por João Auto de Magalhães Castro, Santos Dumont e Augusto Severo, vitimado em 1902 pela explosão do seu balão Pax.19

\footnotetext{
19 Autoria indicada somente para os artigos acerca de João Auto, do professor Raimundo Bertholdo Nunes, representante da revista em Belém, e do submarino, subscrito pelo capitãotenente A. de Sampaio.
} 
A evidenciar a mescla que marcou a publicação em relação às novas potencialidades abertas pela fotografia, cabe destacar as muitas fotos sobre as atividades de Dumont e Severo, contemplados com artigos em duas edições e que, nesse aspecto em particular, aproximava a publicação das congêneres marcadas pelo mundanismo. ${ }^{20}$ Mais uma vez, é difícil estabelecer a procedência desse material, mas pelo menos para o caso dos já citados acidentes de Santos Dumont e Augusto Severo, as fotos publicadas na Ilustração eram idênticas às estampadas em capas do Le Sport Universal Illustré (LE NAUFRAGE..., 1902, p. 292) (LA CATASTROPHE..., 1902, p. 305), ou seja, a impressão na França permitia acesso privilegiado às imagens, tal como ocorria com as ilustrações de outrora, que buscavam o país a fim de oferecer um produto atraente para o público brasileiro a preços convidativos.

A indicar que inexistiam limites para as novidades trazidas pelo progresso científico e que tudo era possível, os leitores eram apresentados a uma eficiente máquina destinada a matar coelhos e tranquilizar agricultores quanto às suas plantações; à renovação do porto de Marselha, na qual os operários trabalhavam doze metros abaixo do nível do mar; a um engenhoso mecanismo concebido para salvar indivíduos enterrados vivos; ao mareorama, grande sucesso na Exposição Universal de 1900 (Paris), antecedente dos simuladores e que reproduzia a sensação e paisagem das viagens marítimas, ao que se poderia acrescer um rol diversificado de itens. Dominar a natureza também estava na agenda dos atletas e o nadador francês Louis Martin Leriche, premiado nas Olimpíadas de 1900, descreveu os esforços em curso para atravessar as cataratas do Niágara e a invenção de um austríaco que the permitiu caminhar sobre o Danúbio, evidenciando o tênue limite entre feitos científicos e eventos inusitados. De fato, a llustração traduziu texto e reproduziu as imagens publicadas em Le Sport Universel Illustré, sem informar o leitor quanto à origem do conteúdo.21

\footnotetext{
${ }^{20}$ Há abundante material, fossem desenhos ou fotografias, sobre a atividade de Severo e Dumont, inclusive reprodução, no número 3, de retrato não datado do último feito por Nadar, mas que não identificou autoria.

${ }^{21}$ A diferença foi de poucos meses entre a Ilustração Brasileira (LERICHE, 1902, p. 208-209) (LERICHE, 1902, p. 267-268) e Le Sport Universel Illustré (LERICHE, 1901, p. 820-821) (LERICHE, 1902, p. 206).
} 
Às conquistas nos diversos campos, fosse da ciência ou dos esportes, somavam-se elementos que atestavam a força do mundo industrial: quantidade de mercadorias e passageiros transportados pelas grandes vias férreas; descrição do maior navio do mundo; de torpedos submarinos; o cotidiano nas minas de carvão; os novos equipamentos e métodos utilizados por bombeiros alemães, para citar alguns exemplos. Tópicos interessantes, como a descrição da pesca no Mar do Norte, a busca pelo âmbar amarelo no Báltico, a fundação do Café Foy em Paris, os benefícios do vinho, uma exposição canina em Londres, cavalos famosos e seus descendentes, ${ }^{22}$ alternavam-se nas páginas da revista, compondo um mosaico diversificado, cujo registro tanto comtemplava o rigor dos experimentos e descobertas originais, quanto amenidades pitorescas de natureza diversa e que não requeriam o domínio de uma cultura científica.

Ainda em concordância com o texto de abertura, a Ilustração Brasileira reservava considerável espaço para produções literárias, além de abrigar ensaios de crítica e considerações sobre a vida e a obra de escritores. Outros setores do mundo da cultura ou estavam ausentes, como o teatro, ou figuraram de maneira bissexta, caso das artes plásticas.

No que respeita aos poemas, exceção feita ao segundo número, todos os demais trouxeram pelo menos um, estivesse reunido em torno da rubrica "Poetas mortos" (Padre Feijó, Antero de Quental e Gonçalves Crespo), fosse sob a forma de transcrição de livros publicados ou projetados (Antônio Patrício, Castro Rebelo, Mariano Gracias, Péthion de Villar), ao que se somavam outras contribuições, a exemplo dos portugueses Eça de Almeida, João Grave, Delfim Guimarães, Júlio Brandão e dos brasileiros Soares Bulcão, Valentim Magalhães, sem esquecer os diplomatas Gonzaga Filho e Carlos Magalhães de Azevedo, que encontravam espaço para atestar seus pendores para as letras.

Na prosa, dois autores, aliás próximos por laços de amizade e integrantes do movimento simbolista português, destacam-se: Júlio Brandão e D. João de Castro. Ambos figuram na Revista de Hoje (Porto, 1894), cujos nove números

\footnotetext{
22 No caso dos cães e cavalos, ainda uma vez há correspondência entre texto e imagem publicados na Ilustração e no Le Sport Universel Illustré, sem que o leitor seja avisado quanto ao fato de se tratar de transcrição.
} 
circularam, sem periodicidade fixa, entre dezembro de 1894 e janeiro de 1896. Brandão assinou quatro textos na Ilustração Brasileira, enquanto D. João de Castro, que atuou como representante do governo português em Bordeaux entre 1900 e 1903, o que certamente o coloca próximo de Sully de Souza, publicou, ao longo de nove números, a novela Paula, e duas outras contribuições em prosa. A revista estampou um curto conto de Coelho Neto, outros de Paulo Sap e Guilherme Gama. Júlio da Costa Lima assinou comédia ambientada no Rio de Janeiro, publicada ao longo de três edições, e o diplomata Henrique Lisboa, duas narrativas de cunho memorialístico. Cabe destacar que não houve preocupação de ilustrar a produção literária.

Em relação à crítica, a contribuição de autores portugueses foi largamente dominante: Maria Amália Vaz de Carvalho, única presença feminina identificável, tratou das crianças na literatura e dos escritores Almeida Garret, Gabriel D’Annunzio e Charlote Brontë; Teófilo Braga ocupou-se de Frei José de Santa Rita Durão; Sequeiros e Abreu analisou a obra do poeta Henrique Heine; enquanto Júlio Brandão discorreu acerca de Júlio Dinis, Almeida Garret, Eça de Queirós, Leon Tolstói e dos portugueses Teixeira Lopes (escultor) e Antônio Carneiro Jr (pintor). Ressalte-se que, nas legendas do desenho a carvão de Carneiro e da maquete de escultura de Lopes, especificou-se que as imagens publicadas foram obtidas por meio de fotografias das obras. Esse cuidado pode ser tomado como indício da superioridade então atribuída à produção de pintores e escultores, em oposição ao registro mecânico do fotógrafo, indivíduo nunca nomeado.

A escassez de análises relativas às artes plásticas era compensada pelo fato de, em quase todos os números, uma página inteira ser reservada à reprodução de pinturas, todas em conformidade com os padrões estéticos dominantes, sem que se fornecessem indicações sobre a autoria, exceção feita a três delas, ${ }^{23}$ ausência que não deixa de surpreender, pois acabava por impor a esse material estatuto meramente ilustrativo.

\footnotetext{
${ }^{3}$ Excetuando-se as duas primeiras edições e a última, as demais trouxeram reproduções de quadros, mas apenas em três ocasiões indicou-se autoria: Benvinda, de Karl Krunt (n. 3), A parte do pobre, de A. Marty (n. 8), e Os bois, do português Silva Porto (n. 10).
} 
Diferentemente do seu colega brasileiro Sully de Souza, que não figurou no índice da revista, D. João de Castro foi colaborador dos mais assíduos e por vezes identificado, nas parcas informações disponíveis sobre a sua vida, como diretor da revista, o que não surpreende pois, além da produção ficcional, assinou com suas iniciais a seção "Ecos da Europa", desprovida de ilustrações e que sempre ocupou a última página de cada número. Essa particularizava-se pelo ecletismo e tanto poderia dedicar todo o espaço à crítica de uma única obra literária, o que ocorreu em relação aos seus amigos próximos, os escritores Raul Brandão e Júlio Brandão, que não guardavam parentesco mas que integravam o movimento simbolista português, ou mesclar, em proporções variáveis, análise de livros recém-publicados no Brasil, em Portugal ou na França, faits-divers, eventos políticos, curiosidades de toda ordem, fazendo jus ao título, pois se tratava de comentários diversificados, sem intenção de dar conta sistemática de aspectos políticos, econômicos, sociais ou culturais. Ao que parece, seu responsável tinha autonomia para escolher os tópicos que the parecessem atuais e interessantes, compondo um mosaico que não enseja caracterização precisa.

Apenas no número inaugural, "Ecos da Europa" não foi antecedida pela outra seção fixa da revista, "Correio da Moda", subscrita pela Baronesa de Mayerville (n. 1 a 7), Condessa de P*** (n. 8 ao 10) e Formosina (n. 11 e 12), pseudônimos não identificados. O texto da seção estabelecia diálogo direto com as leitoras e fazia alusão às tendências e novidades parisienses, ${ }^{24} \mathrm{em}$ termos de cores, tecidos, modelos e adereços, sugestões destinadas a um público sofisticado. Único conteúdo explicitamente dirigido ao público feminino, "Correio da Moda" sempre ocupou quatro páginas (16,6\% das 24 páginas de cada edição), duas consagradas aos vestidos, uma aos chapéus enquanto a outra trazia texto e breve comentário acerca de cada estampa publicada, cabendo esclarecer que não se tratava de fotografia.

\footnotetext{
${ }^{4}$ Enquanto a seção foi assinada pela Baronesa, havia abundantes referências aos eventos que ritmavam a vida parisiense, sugerindo que ela residia na cidade. Essas menções estão ausentes nos textos das sucessoras. Os modelos de chapéus, presentes nos números 1 a 10, provinham da casa Lenthéric, um dos anunciantes da llustração, e nos dois últimos do Palais de la Mode. Para os vestidos, a loja West End foi citada nos números 4, 11 e 12, prática que parece prenunciar a mescla entre serviço e propaganda, comum nas revistas femininas. É lícito supor, nos casos citados, a produção do material iconográfico fosse de responsabilidade das empresas.
} 
A análise da llustração revelou que os responsáveis não pareciam preocupados em precisar autorias e o descaso, especialmente em relação à parte iconográfica, é marcante, fosse em relação aos responsáveis pelo original (desenho, pintura, fotografia) ou pela preparação do mesmo para a impressão. Por vezes é possível identificar letras e, em raras oportunidades, a assinatura, caso dos gravadores Paul Jonnard Pacel e R. Bong, provavelmente o alemão Richard Bong, que acresceu as letras X A, para identificar que se tratava de xilo de sua autoria. Contudo, o trabalho não deve ter sido feito especialmente para a revista, pelo contrário, o mais provável é que fossem matrizes já utilizadas em outras publicações. No que respeita ao ateliê fotográfico, o destaque coube a Ducourtioux, nome presente na ilustração da capa do invólucro e em outra vintena de ocasiões, montante modesto diante das quase três centenas de imagens publicadas. Sabe-se que, em 1890, juntamente com Huillard e Verdoux, ele oferecia serviços de fotogravura, cromotipografia e fotolitografia na Rue Jacob 23, Paris (SAUVAGE, 2010).

O referido descaso também se verifica, ainda que em menor grau, com a parte textual. A listagem dos colaboradores identificados encontra-se na Tabela n. 2, na qual se especifica, na primeira coluna, os que figuraram como autores, aí incluídas as produções literárias, textos já publicados em outros periódicos, bem como produções de autores já falecidos, ou seja, a presença de um autor nem sempre implica engajamento ativo na publicação. A segunda coluna, por sua vez, arrola o número total de contribuições de cada autor. Contribuições que se estenderam por mais de um número foram indicadas em negrito, pois esse aspecto é importante para avaliar o peso do autor no conjunto da publicação. Assim, por exemplo, D. João de Castro, respondeu pela seção "Ecos da Europa", com 12 entradas, e por três produções literárias, sendo que a novela Paula foi publicada ao longo de nove números, portanto, o seu nome foi estampado 23 vezes na llustração Brasileira, de longe o colaborador mais assíduo. 
Tabela 2 - Autores identificados e quantidade de vezes que figuraram na /lustração Brasileira

\begin{tabular}{|c|c|}
\hline Autoria de artigos, notas, críticas, produção literária, seções & $\begin{array}{l}\text { Presença } \\
\text { na } \\
\text { llustração }\end{array}$ \\
\hline D. João de Castro & 23 \\
\hline Júlio Brandão & 12 \\
\hline Baronesa de Mayerville & 07 \\
\hline Maria Amália Vaz de Carvalho & 05 \\
\hline $\begin{array}{l}\text { Henrique Carlos Ribeiro de Lisboa, Hilário de Gouveia, J. De } \\
\text { Sequeiros e Abreu }\end{array}$ & 04 \\
\hline Condessa P..., Phétion de Vilar, & 03 \\
\hline $\begin{array}{l}\text { Carlos Magalhães de Azeredo, Eça de Queirós, Formosina, Gonzaga } \\
\text { Filho, Louis Leriche, Mariano Gracias, Marques de Maricá, Padre } \\
\text { Antônio Vieira, Soares Bulcão, Victor Hugo, Teófilo Braga }\end{array}$ & 02 \\
\hline $\begin{array}{l}\text { A. Arène, A. De Sampaio, Albion W. Tourgée, Antero de Quental, } \\
\text { Antonio Carvalhal, Antônio Patrício, Aureliano Scholl, Barão do Rio } \\
\text { Branco, Barão Homem de Melo, Bernardim Ribeiro, Castro Rebelo, } \\
\text { Coelho Neto, Delfim Guimarães, Diogo Antônio Feijó, Domício da } \\
\text { Gama, E. M. De Voguée, Eça de Almeida, Frei Heitor Pinto, Gonçalves } \\
\text { Crespo, Guilherme Gama, H. Harz, João Grave, José Antônio de } \\
\text { Azevedo Castro, Joseph Gourdon, Jules Claretie, Júlio Pires, Olavo } \\
\text { Bilac, Paulo Sap, Queirós Ribeiro, R. Bertoldo Nunes, Ramalho } \\
\text { Ortigão, Reginald Mac-Kenna, Santos Porto, Tillement Fontes, } \\
\text { Valentim Magalhães, Visconde de Ouguela }\end{array}$ & 01 \\
\hline
\end{tabular}

Legenda: itálico para autores de cuja obra foram extraídas frases; negrito para autores que tiveram uma contribuição publicada em mais de um número.

Fonte: Elaborado pelo autor, 2020.

\section{Considerações finais}

Foi no final do século XIX, com os avanços técnicos que permitiram a impressão direta da fotografia, que os periódicos conheceram significativa inflexão em diferentes sentidos: projeto gráfico, objetivos, natureza e tratamento do conteúdo, o que deu origem aos muitos títulos que inundaram o mercado de periódicos ao longo de todo século XX. Pode-se mesmo afirmar que o sentido da palavra revista ganhou em precisão, tanto que deixou de vigorar a prática, antes corriqueira entre os responsáveis de uma autonomeada "revista", de denominála "jornal", para indicar que se tratava de publicação seriada. O igualmente 
arraigado hábito de tentar elidir a distância em relação ao livro, expresso na numeração contínua das páginas e posterior encadernação dos exemplares para formar um volume, acabou por ser abandonado, ou seja, assumiu-se o caráter passageiro e ligado ao cotidiano imediato desses impressos, o que os distanciava dos livros, mas também das folhas diárias, em função de sua periodicidade mais alongada e do tratamento dispensado aos assuntos. Coube à maioria das revistas literárias e culturais ${ }^{25}$ manter a apresentação sóbria, não romper os liames com os livros e fazer uso moderado da imagem, estratégias para marcar o seu distanciamento do gênero mundano.

Entretanto, se analiticamente as diferenças podem ser estabelecidas com precisão, na prática as classificações não necessariamente correspondem aos modelos. A llustração Brasileira é, nesse sentido, um exemplo interessante pelas suas singularidades e ambiguidades, a começar pelo fato de ser difícil precisar se a revista se constituía num negócio, a exemplo de contemporâneas como a Revista da Semana, ou se era uma iniciativa que contava com apoio, direto ou indireto, do poder público. Não há dúvidas em relação à proximidade, se não com o Itamarati, pelo menos com o corpo diplomático e suas redes de sociabilidade, como revelou o rol de colaboradores.

O conteúdo da publicação permite tomá-la como uma espécie de elo entre impressos típicos do século XIX e os magazines ilustrados que triunfaram a partir da centúria seguinte. Isso porque em suas páginas é possível divisar preocupações que remetem para o gênero conhecimentos úteis, ou seja, periódicos que objetivavam fornecer ao leitor um repertório de saberes que colaborariam para a sua instrução, aqui entendido na chave, bem mais restritiva, da formação do sentimento nacional. Isso porque estava em jogo, como se declarou explicitamente, o registro das glórias, dos progressos e dos homens ilustres de todos os tempos, num esforço de documentar não apenas o momento atual, mas a trajetória da nação. Realizar tal intento envolvia um processo de seleção que recaiu, com especial ênfase, em figuras ligadas ao

\footnotetext{
25 Tais observações não fazem jus à proposta das revistas de vanguarda, a exemplo de Klaxon (SP, 1922-1923), daí a necessidade de analisar os casos concretos.
} 
Império, ainda que não estivessem ausentes personalidades republicanas então no exercício do poder.

A abordagem minuciosa repetia-se mesmo quando o tema não era o Brasil, como se observou em relação aos personagens falecidos durante a circulação da revista. A ambiguidade manifestava-se no fato de a ênfase não recair na notícia em si, mas em amplas considerações acerca dos seus efeitos no cenário internacional, noutros termos, estavam submetidos ao tom proveniente da diplomacia e de seus praticantes, que assinavam essas análises. Se a motivação inicial era um fato da atualidade, o tratamento, por sua vez, tendia a superar o episódico e acaba por se afastar dos protocolos da linguagem jornalística.

Ainda no mesmo diapasão, pode-se incluir os artigos consagrados às descobertas e experiências em diferentes áreas das ciências, cuja compreensão pressupunha o domínio de vocabulário e princípios específicos, o que aproximava a revista, desta feita, das publicações especializadas. Contudo, não faltou material de vulgarização, no qual predominavam as curiosidades, a atestar as maravilhas trazidas pelo progresso e que infundiam confiança nas potencialidades do mundo industrial. Nesse âmbito, os meios de transporte, fossem automóveis, ferroviais, navios de passageiros ou de guerra, submarinos e aviões receberam particular atenção. Contudo, as ausências também são expressivas: nada de caricaturas, charadas, advinhas, conselhos, eventos sociais (casamentos, aniversários, nascimentos, recepções e bailes), seções que estabelecessem diálogo direto com o leitor, tão típicas das revistas ilustradas e de variedades, outro indício do público imaginado. A moda, por sua vez, era sofisticada e dirigida às consumidoras com significativa disponibilidade econômica.

No que tange à cultura, predominou a crítica literária, enquanto a produção ficcional provinha de autores contemporâneos, ainda que os consagrados tenham sido homenageados sob a rubrica "poetas mortos". A incorporação da produção literária era parte incontornável nos magazines que se difundiram nas décadas iniciais do Novecentos, devendo-se notar, contudo, a ausência do cronista de temas leves, tarefa que talvez devesse ser desempenhada, na Ilustração Brasileira, pela seção "Ecos da Europa”, mas cujos resultados podem 
ser considerados pouco exitosos. A análise dos colaboradores e das temáticas permite supor que esse conteúdo cultural estava sob a responsabilidade dos portugueses D. João de Castro e Júlio Brandão, enquanto o diretor declarado, mas nunca mencionado, Sully de Souza, deveria responder pelos demais assuntos.

A mobilização das imagens, fossem fotografias ou estampas, aponta para a articulação texto/iconografia, mesmo que nem sempre a diagramação tenha sido realizada de modo a contemplar, na mesma página, os dois conteúdos. Se, sob esse aspecto, a revista subscrevia os novos padrões em voga, cabe observar a sobrevivência de práticas típicas das revistas ilustradas lançadas na Europa a partir da década de 1840 - já afastadas do ideal de difundir saberes úteis em prol das novidades - cuja ambição era a de seduzir o leitor com belas imagens, que ocupavam uma ou mesmo duas páginas inteiras, acompanhadas de explicações na seção "As nossas gravuras", que orientavam o olhar, forneciam dados sobre o autor e/ou o objeto/personagem representado.

A Ilustração Brasileira não trouxe a referida seção e as estampas ou fotografias figuravam de maneira isolada, com legendas por demais sucintas e, no caso de obras de arte, muitas vezes sem nem mesmo mencionar autoria. Essa utilização, sem reproduzir propriamente o modelo anterior e tampouco vincular-se à reportagem, novidade dos magazines, coloca a publicação numa espécie de zona de transição, com mescla entre procedimentos tradicionais do campo das revistas ilustradas (fossem as comprometidas com os conhecimentos úteis ou aquelas que se ocupavam das novidades) e as novas formas de difusão da informação textual e imagética, possibilitadas pela aceleração das comunicações e os avanços nas técnicas de impressão.

Nesse sentido, em vez de participar do novo tempo, dominado pelos magazines ilustrados e de variedades, a Ilustração Brasileira pode ser vista, no máximo, como um periódico de transição, contrariamente à voz corrente na historiografia, que se contenta em classificar a partir da presença/ausência da fotografia.

É provável que esse hibridismo - para não dizer indefinição - pudesse ser melhor compreendido se fosse possível estabelecer, de maneira mais precisa, as 
razões do lançamento da publicação, a origem dos recursos financeiros, a tiragem e se houvesse dados, mesmo que indiretos, sobre sua recepção, tendo que vista que a pesquisa em hemerotecas digitais do Brasil e de Portugal revelouse, até o momento, pouco frutífera. A julgar pelo conteúdo, a revista dirigia-se ao leitor culto brasileiro, uma vez que a presença de colaboradores portugueses não significou abertura de espaço para a história ou a atualidade daquele país, praticamente ausente da revista, exceção feita à produção literária, contemplada em várias oportunidades, uma vez que, como destacado, cabia a escritores portugueses responder por esse conteúdo. Tampouco se tratava de fazer propaganda do Brasil no exterior, o que não apenas demandaria que a edição fosse, pelo menos, bilíngue, mas também apresentasse outra abordagem, caso o objetivo fosse apresentar o país para estrangeiros. As motivações permanecem, portanto, uma questão em aberto.

Em síntese, várias questões seguem sem respostas, mas o exemplo alerta para a necessidade de análises circunstanciadas dos títulos lançados no início do século XX, de modo a distinguir suas peculiaridades, em vez de simplesmente tomá-los como um conjunto amorfo e rotulá-los de revistas ilustradas e de variedades, aos quais se agregam, ainda, o adjetivo inovador, em função da utilização da fotografia. E, por fim, cabe mencionar o inspirador trecho de Brito Broca que, possivelmente ao folhear a revista, deu-se conta do peso dos diplomatas em suas páginas, o que o levou a atribuir a iniciativa a Rio Branco, paternidade, até o momento, não confirmada. Porém, a suposição expressa a força do personagem, afinal, para Broca pareceu evidente que o empreendimento só poderia ser creditado ao Barão. 


\section{Referências}

A PRIMAVERA. A Província, Pernambuco, ano 24, n. 240, p. 1, 22 out. 1901. Disponível em: http://memoria.bn.br/DocReader/128066_01/10983. Acesso em: 10 ago. 2020.

A. A. [AZEVEDO, Artur]. Livros, Folhetos e Revistas. O País, Rio de Janeiro, ano 27, n. 6183, p. 1, 12 set. 1901. Disponível em:

http://memoria.bn.br/DocReader/178691_03/3097. Acesso em: 11 ago. 2020.

ANDRADE, Joaquim Marçal Ferreira de. História da fotorreportagem no Brasil: a fotografia na imprensa do Rio de Janeiro de 1839 a 1900. Rio de Janeiro: Elsevier, 2004.

BOUCHON, Georges (ed.). Histoire d'une imprimerie bordelaise (1600-1900). Bordeaux: Imprimeries G. Gounouilhou, 1901. Disponível em: https://archive.org/details/histoireduneimprO0boucuoft/page/346/mode/2up. Acesso em: 12 jun. 2020.

BROCA, Brito. A vida literária no Brasil: 1900. 4. ed. Rio de Janeiro: José Olympio: Academia Brasileira de Letras, 2004.

CORRÊA, Luiz Felipe de Seixas. O Barão do Rio Branco: missão em Berlim, 19011902. Brasília: Fundação Alexandre de Gusmão, 2009. Disponível em:

http://funag.gov.br/biblioteca/index.php?route=product/product\&product_id=45 8. Acesso em: 11 ago. 2020.

CRUZ, Heloisa de Faria (org.). São Paulo em revista: catálogo de publicações da imprensa cultural e de variedades paulistana 1870-1930. São Paulo: Arquivo do Estado, 1997.

DIMAS, Antonio. Tempos eufóricos: análise da revista Kosmos 1904-1909. São Paulo: Ática, 1983.

ELOY [Artur Azevedo]. Croniqueta. A Estação, Rio de Janeiro, ano 30, n. 17, p. 100, 15 set. 1901. Disponível em: http://memoria.bn.br/DocReader/709816/7274. Acesso em: 09 ago. 2020.

FERREIRA, Orlando da Costa. Imagem e letra: introdução à bibliologia brasileira: a imagem gravada. 2. ed. São Paulo: Edusp, 1994.

FEYEL, Gilles. Naissance, constitution progressive et épanouissement d'un genre de presse aux limites floues: le magazine. Réseaux, Paris, v. 105, n. 1, p. 19-51, 2001. Disponível em: https://www.cairn.info/revue-reseaux1-2001-1-page-19.htm. Acesso em: 10 ago. 2020. 
FONSECA, Letícia Pedruzzi. Uma revolução gráfica: Julião Machado e as revistas ilustradas no Brasil, 1895-1898. São Paulo: Blucher, 2009. Disponível em: https://openaccess.blucher.com.br/article-list/uma-revolucao-grafica-juliaomachado-e-as-revistas-ilustradas-no-brasil-312/list\#undefined. Acesso em : 08 ago. 2020.

FRANÇA. Ilustração Brasileira, Paris, ano 1, n. 9, p. 208, abr. 1902. Disponível em: http://memoria.bn.br/DocReader/107468/239. Acesso em: 10 ago. 20,20.

GERVAIS, Thierry. D’après photographie : premiers usages de la photographie dans le journal L'Illustration (1843-1859). Études photographiques, Paris p. 56 85, 13 jul. 2003. Disponível em:

https://journals.openedition.org/etudesphotographiques/347. Acesso em: 09 ago. 2020.

GERVAIS, Thierry. De part et d'autre de la garde barrière: les errances techniques dans l'usage de la photographie au sein du journal L'Illustration (1880-1900). Études photographiques, Paris, p. 1-24, 05 ago. 2009. Disponível em: http://journals.openedition.org/etudesphotographiques/2663. Acesso em: 09 jun. 2020.

GERVAIS, Thierry. La similigravure: le récit d'une invention (1878-1893). Nouvelles de l'estampe, Paris, n. 229, 1-25, 2010. Disponível em:

http://journals.openedition.org/estampe/1337. Acesso em: 09 ago. 2020.

HUGO, Victor. Pensamentos. Ilustração Brasileira, Paris, ano 1, n. 7, p. 150, mar. 1902. Disponível em: http://memoria.bn.br/DocReader/107468/176. Acesso em: 10 ago. 2020.

ILUSTRAÇÃO BRASILEIRA, Paris, ano 1, n. 1, p. 2, agosto de 1901a. Disponível em: http://memoria.bn.br/DocReader/107468/4. Acesso em: 10 ago. 2020.

ILUSTRAÇÃO BRASILEIRA. O Fluminense, Niterói, ano 24, n. 4644, p. 1, 24 ago. 1901b. Disponível em: http://memoria.bn.br/DocReader/100439_04/2053. Acesso em: 11 ago. 2020.

JACKSON, Mason. The pictorial press. It's origin and progress. London: Hurst and Blackett, 1885. Disponível em: http://www.gutenberg.org/ebooks/36417. Acesso em: 10 ago. 2020.

JORGE, Artur Guimarães de Araújo. Rio Branco e as fronteiras do Brasil. Uma introdução às obras do Barão do Rio Branco. Brasília: Senado Federal, 1999. 
LA CATASTROPHE DU “PAX”. Le Sport Universel Illustré, Paris, n. 304, p. 305, 18 maio 1902. Disponível em:

https://gallica.bnf.fr/ark:/12148/bpt6k65280896/f311.item.zoom. Acesso em: 11 ago. 2020.

LE NAUFRAGE DU SANTOS-DUMONT... Le Sport Universel Illustré, Paris, n. 292, p. 113, 23 fev. 1902. Disponível em:

https://gallica.bnf.fr/ark:/12148/bpt6k65280896/f119.item. Acesso em: 11 ago. 2020.

LERICHE, Louis. Os heróis do Niágara. Ilustração Brasileira, Paris, ano 1, n. 9, p. 208-209, abr. 1902. Disponível em: http://memoria.bn.br/DocReader/107468/239. Acesso em: 10 ago. 2020.

LERICHE, Louis. Um passeio a pé pelo Danúbio. Ilustração Brasileira, Paris, ano 1, n. 12, p. 267-268, jul. 1902. Disponível em:

http://memoria.bn.br/DocReader/107468/310. Acesso em: 10 ago. 2020.

LERICHE, Louis. Les héros du Niagara. Le Sport Universel Illustré, Paris, n. 283, p. 820-821, 21 dez. 1901. Disponível em:

https://gallica.bnf.fr/ark:/12148/bpt6k6528432s/f400.item. Acesso em: 11 ago.

2020.

LERICHE, Louis. Une course a pied sur le Danube. Le Sport Universel Illustré, Paris, n. 297, p. 206, 30 maio 1902. Disponível em:

https://gallica.bnf.fr/ark:/12148/bpt6k65280896/f212.item. Acesso em: 11 ago. 2020.

LUCA, Tania Regina de. A llustração (1884-1892): circulação de textos e imagens entre Paris, Lisboa e Ro de Janeiro. São Paulo: Unesp : Fapesp, 2018.

MARICÁ, Marques de. Pedras soltas. Ilustração Brasileira, Paris, ano 1, n. 11, p. 247, jun. 1902. Disponível em: http://memoria.bn.br/DocReader/107468/286. Acesso em: 10 ago. 2020.

MARTINS, Ana Luiza. Revistas em revista: imprensa e práticas culturais em tempos de república (1890-1922). São Paulo: Edusp : Fapesp : Imprensa Oficial do Estado, 2001.

O NAUFRÁGIO DO "SANTOS DUMONT". Ilustração Brasileira, Paris, ano 1, n. 9, p. 197-198, abr. 1902. Disponível em: http://memoria.bn.br/DocReader/107468/228. Acesso em: 10 ago. 2020.

ORTIGÃO, Ramalho. Fragmentos. Ilustração Brasileira, Paris, ano 1, n. 2, p. 41, ago. 1901. Disponível em: http://memoria.bn.br/DocReader/107468/47. Acesso em: 10 ago. 2020. 
PINSARD, Jules. L'lllustration du livre moderne et la photographie. Paris: Charles Mendel, 1897. Disponível em: https://gallica.bnf.fr/ark:/12148/bpt6k1179002z. Acesso em: 09 ago. 2020.

PORTA, Frederico. Dicionário de artes gráficas. Porto Alegre: Globo, 1958.

SANTOS, Luís Cláudio Villafañe Gomes. O evangélio do barão: Rio Branco e a identidade brasileira. São Paulo: Unesp, 2012.

SAUVAGE, Anne-Marie. L'affiche en couleurs à la fin du XIXe siècle. Nouvelles de l'estampe, Paris, n. 230, p. 1-6, 2010. Disponível em:

http://journals.openedition.org/estampe/1326. Acesso em: 12 set. 2020.

SODRÉ, Nelson Werneck. História da imprensa no Brasil. 4. ed. Rio de Janeiro: Mauad, 1999. 